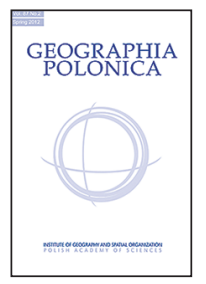

\title{
EMPIRICAL AND COMPUTATIONAL ASSESSMENT OF THE URBAN HEAT ISLAND PHENOMENON AND RELATED MITIGATION MEASURES
}

\author{
Ardeshir Mahdavi - Kristina Kiesel - Milena Vuckovic \\ Department of Building Physics and Building Ecology \\ Vienna University of Technology \\ Karlsplatz 13, 1040 Vienna: Austria \\ e-mails: bpi@tuwien.ac.at • kristina.kiesel@tuwien.ac.at • milena.vuckovic@tuwien.ac.at
}

\begin{abstract}
A central strand of research work in the realm of urban physics aims at a better understanding of the variance in microclimatic conditions due to factors such as building agglomeration density, anthropogenic heat production, traffic intensity, presence and extent of green areas and bodies of water, etc. This research has been motivated in part by phenomena associated with climate change and urban heat islands (UHI) and their implications for the urban microclimate. Note that the characteristics and evolution of the urban microclimate is not only relevant to people's experience of outdoor thermal conditions in the cities. It can be argued that the solid understanding of the temporal and spatial variance of urban microclimate represents a prerequisite for the reliable assessment of the thermal performance of buildings (energy requirements, indoor thermal conditions). In this context, the present paper entails a three-fold contribution. First, the existence and extent of the UHI phenomena are documented for a number of Central-European cities. Second, a number of variables of the urban environment are identified that are hypothesized to influence UHI and the urban microclimate variance. These variables, which pertain to both geometric (morphological) and semantic (material-related) urban features are captured within a formal and systematic framework. Third, to support the process of design and evaluation of UHI mitigation measures, the potential of both numerical (simulation-based) applications and empirically-based urban microclimate models are explored.
\end{abstract}

\section{Keywords}

urban climate $\bullet$ urban heat island $\bullet$ mitigation measure $\bullet$ modeling $\bullet$ evaluation

\section{Introduction}

An increasing number of people live in cities and are therefore influenced by the urban microclimate. The microclimate varies sig- nificantly within a city depending on factors such as urbanization, presence and density of industrial or commercial buildings, green areas, bodies of water, etc. (Alexandri 2007; Grimmond 2007). Furthermore, the geom- 
etry, spacing, and orientation of buildings and surrounding open areas greatly influence the climate in the city (Unger 2004; Kleerekoper et al. 2012; Shishegar 2013). Observations in many cities around the world point to significantly higher urban temperatures than the surrounding rural environment. This circumstance is referred to as the urban heat island (UHI) phenomenon (see, for example: Oke 1981; Voogt 2002; Arnfield 2003; Błażejczyk et al. 2006; Gaffin et al. 2008). Increase in average temperatures is believed to adversely affect the health of people living in cities (Harlan et al. 2011). Additionally, higher air temperatures have a direct effect on the energy use due to increased deployment of air conditioning (Akbari 2005). In this context, this paper presents the results of an ongoing research project (Central Europe Program 2011). First the existence and extent of the UHI phenomena are documented for a number of Central-European cities. Thereby, certain features of the urban environment are hypothesized to influence $\mathrm{UHI}$ and the urban microclimate variance. The related variables, which pertain to both geometric (morphological) and semantic (material-related) urban features are captured within a systematic framework. Moreover, to support the process of design and evaluation of UHI mitigation measures, the potential of both numerical (simulation-based) applications and empirically-based urban microclimate models are explored.

\section{Background}

Numerous studies have been carried out discussing and quantifying the UHI phenomenon (see, for example: Arnfield 2003; Błażejczyk et al. 2006). Efforts have been made to describe the characteristics and patterns of UHI (Voogt 2002; Hart \& Sailor 2007). Observations have shown that the UHI phenomenon shows different characteristics during different seasons (Gaffin et al. 2008) and that is pronounced differently during the night and the day (Oke 1981). Furthermore, the intensity of urban heat islands is believed to rise proportionally to the size and population of the urban area (Oke 1972). More recently, Gaffin et al. (2008) performed a detailed spatial study of New York City's current UHI and concluded that summer and fall periods were generally the strongest UHI seasons, consistent with seasonal wind speed changes in the area.

The UHI is defined as the difference between urban and rural air temperature (Oke 1972). Generally, heat island intensities are quantified in the range of 1 to $3 \mathrm{~K}$, but under certain atmospheric and surface conditions can be as high as $12 \mathrm{~K}$ (Voogt 2002). Material properties of urban surfaces (Grimmond et al. 1991; Akbari et al. 2001) as well as anthropogenic heat emission (Taha 1997) can result in higher urban temperatures.

\section{The Urban Heat Island in central Europe}

The present contribution focuses on the frequency, magnitude, and time-dependent (diurnal and nocturnal) UHI intensity distribution (during a reference week) and the long-term development of urban and rural temperatures in seven Central-European cities, namely Budapest, Ljubljana, Modena, Padua, Prague, Stuttgart, Vienna, and Warsaw. The magnitude of the UHI effect can be expressed in terms of urban heat island intensity $(\Delta \theta)$. This term denotes the temperature difference (in K) between simultaneously measured urban and rural temperatures. The specific aim of this paper is to identify and evaluate the extent of the UHI effect and its variance in the broader geographical context of the participating cities.

Table 1 includes some general information about our research project's participating cities in terms of area, population, latitude, longitude, and altitude. Additional information concerning cities' location and topology is provided in Table 2.

As mentioned before, UHI intensity in observed urban areas was derived for a reference summer week (with high air tempera- 
Table 1. Information about the participating cities

\begin{tabular}{|l|c|c|c|c|c|}
\hline \multicolumn{1}{|c|}{ City } & $\begin{array}{c}\text { Area } \\
{\left[\mathrm{km}^{2}\right]}\end{array}$ & $\begin{array}{c}\text { Population } \\
{[\text { millions }]}\end{array}$ & Latitude & Longitude & $\begin{array}{c}\text { Altitude } \\
{[\mathrm{m}]}\end{array}$ \\
\hline Budapest & 525 & 1.74 & $47^{\circ} 30^{\prime} \mathrm{N}$ & $19^{\circ} 03^{\prime} \mathrm{E}$ & $90-529$ \\
Ljubljana & 275 & 0.28 & $46^{\circ} 03^{\prime} \mathrm{N}$ & $14^{\circ} 30^{\prime} \mathrm{E}$ & $261-794$ \\
Modena & 183 & 0.18 & $44^{\circ} 39^{\prime} \mathrm{N}$ & $10^{\circ} 55^{\prime} \mathrm{E}$ & 34 \\
Padua & 93 & 0.21 & $45^{\circ} 25^{\prime} \mathrm{N}$ & $11^{\circ} 52^{\prime} \mathrm{E}$ & $8-21$ \\
Prague & 496 & 1.26 & $50^{\circ} 05^{\prime} \mathrm{N}$ & $14^{\circ} 25^{\prime} \mathrm{E}$ & $177-399$ \\
Stuttgart & 207 & 0.60 & $48^{\circ} 46^{\prime} \mathrm{N}$ & $9^{\circ} 10^{\prime} \mathrm{E}$ & $207-548$ \\
Vienna & 415 & 1.73 & $48^{\circ} 12^{\prime} \mathrm{N}$ & $16^{\circ} 22^{\prime} \mathrm{E}$ & $151-543$ \\
Warsaw & 517 & 1.70 & $52^{\circ} 13^{\prime} \mathrm{N}$ & $21^{\circ} 00^{\prime} \mathrm{E}$ & $76-122$ \\
\hline
\end{tabular}

Table 2. Information about the urban topology

\begin{tabular}{|c|c|}
\hline City & Topology \\
\hline Vienna & $\begin{array}{l}\text { Vienna is located in north-eastern Austria, at the eastern most extension of the Alps in the } \\
\text { Vienna Basin. }\end{array}$ \\
\hline Stuttgart & $\begin{array}{l}\text { Stuttgart's center lies in a Keuper sink and is surrounded by hills. Stuttgart is spread across } \\
\text { several hills, valleys and parks. }\end{array}$ \\
\hline Padua & $\begin{array}{l}\text { Padua is located at Bacchiglione River, } 40 \mathrm{~km} \text { west of Venice and } 29 \mathrm{~km} \text { southeast of Vicenza. } \\
\text { The Brenta River, which once ran through the city, still touches the northern districts. To the } \\
\text { city's south west lie the Euganaean Hills. }\end{array}$ \\
\hline Budapest & $\begin{array}{l}\text { The Danube River divides Budapest into two parts. On the left bank the Buda is located, with } \\
\text { over } 20 \text { hills within the territory of the capital, and on the right bank the flat area of Pest } \\
\text { is located with its massive housing, as well as commercial and industrial areas. }\end{array}$ \\
\hline Prague & Prague is situated on the Vltava river in the center of the Bohemian Basin. \\
\hline Modena & $\begin{array}{l}\text { Modena is bounded by the two rivers Secchia and Panaro, both affluent of the Po River. The } \\
\text { Apennines ranges begin some } 10 \mathrm{~km} \text { from the city, to the south. }\end{array}$ \\
\hline Warsaw & $\begin{array}{l}\text { Warsaw is located some } 260 \mathrm{~km} \text { from the Baltic Sea and } 300 \mathrm{~km} \text { from the Carpathian Moun- } \\
\text { tains. Furthermore, Warsaw is located in the heartland of the Masovian Plain. }\end{array}$ \\
\hline Ljubljana & Ljubljana is located in the Ljubljana Basin between the Alps and the Karst Plateau. \\
\hline
\end{tabular}

ture and relatively low wind velocity) selected by each participating city independently. The collected information included hourly data on air temperature, wind speed, and precipitation from two representative weather stations (one urban and one rural).

To obtain a long-term impression of the urban and rural temperature development, mean annual (urban and rural) temperatures and $U H I$ values were derived for a period of up to 30 years, namely from 1980 to 2011 (Modena, Prague, Stuttgart, Warsaw), from 1994 to 2011 (Vienna, Padua), from 2000 to 2011 (Budapest).

Table 3 provides an overview of the time periods used for both the short-term and the long-term analyses. Table 4 provides an overview of selected urban and rural weather stations.

\section{Short-term analyses of the observations}

Figure 1 shows the cumulative frequency distribution of UHI values for the participating cities for the aforementioned summer reference week. Figures 2 and 3 show for a reference summer day (representing the reference week) the hourly values (local time) of urban temperature and the hourly $\mathrm{UHI}$ values respectively. 
Table 3. Overview for the data sets used for the analysis

\begin{tabular}{|l|c|c|c|}
\hline \multirow{2}{*}{} & \multirow{2}{*}{ Reference week } & \multicolumn{2}{|c|}{ Long-term climate data } \\
\cline { 2 - 4 } & & urban station & rural station \\
\hline Budapest & $20-26.8 .2011$ & $2000-2011$ & $2000-2011$ \\
Ljubljana & $20-26.8 .2011$ & $1980-2011$ & $1980-2011$ \\
Modena & $20-26.8 .2011$ & $1980-2010$ & $1980-2009$ \\
Padua & $18-24.8 .2011$ & $1994-2011$ & $1994-2011$ \\
Prague & $8-14.7 .2010$ & $1980-2011$ & $1980-2011$ \\
Stuttgart & $20-26.8 .2011$ & $1981-2011$ & $1980-2011$ \\
Vienna & $20-26.7 .2011$ & $1994-2011$ & $1994-2011$ \\
Warsaw & $9-15.6 .2008$ & $1980-2011$ & $1980-2011$ \\
\hline
\end{tabular}

Table 4. Overview for the selected urban and rural weather stations

\begin{tabular}{|l|c|c|c|c|}
\hline \multirow{2}{*}{} & \multicolumn{2}{|c|}{ Urban station } & \multicolumn{2}{c|}{ Rural station } \\
\cline { 2 - 5 } & latitude & longitude & latitude & longitude \\
\hline Budapest & $47^{\circ} 28^{\prime} \mathrm{N}$ & $19^{\circ} 04^{\prime} \mathrm{E}$ & $47^{\circ} 14^{\prime} \mathrm{N}$ & $19^{\circ} 22^{\prime} \mathrm{E}$ \\
Ljubljana & $46^{\circ} 07^{\prime} \mathrm{N}$ & $14^{\circ} 52^{\prime} \mathrm{E}$ & $46^{\circ} 22^{\prime} \mathrm{N}$ & $14^{\circ} 22^{\prime} \mathrm{E}$ \\
Modena & $44^{\circ} 39^{\prime} \mathrm{N}$ & $10^{\circ} 55^{\prime} \mathrm{E}$ & $44^{\circ} 50^{\prime} \mathrm{N}$ & $11^{\circ} 17^{\prime} \mathrm{E}$ \\
Padua & $45^{\circ} 24^{\prime} \mathrm{N}$ & $11^{\circ} 53^{\prime} \mathrm{E}$ & $45^{\circ} 20^{\prime} \mathrm{N}$ & $11^{\circ} 57^{\prime} \mathrm{E}$ \\
Prague & $50^{\circ} 05^{\prime} \mathrm{N}$ & $14^{\circ} 26^{\prime} \mathrm{E}$ & $50^{\circ} 06^{\prime} \mathrm{N}$ & $14^{\circ} 15^{\prime} \mathrm{E}$ \\
Stuttgart & $48^{\circ} 47^{\prime} \mathrm{N}$ & $9^{\circ} 13^{\prime} \mathrm{E}$ & $48^{\circ} 41^{\prime} \mathrm{N}$ & $9^{\circ} 13^{\prime} \mathrm{E}$ \\
Vienna & $48^{\circ} 11^{\prime} \mathrm{N}$ & $16^{\circ} 22^{\prime} \mathrm{E}$ & $47^{\circ} 58^{\prime} \mathrm{N}$ & $16^{\circ} 30^{\prime} \mathrm{E}$ \\
Warsaw & $52^{\circ} 13^{\prime} \mathrm{N}$ & $20^{\circ} 58^{\prime} \mathrm{E}$ & $52^{\circ} 30^{\prime} \mathrm{N}$ & $21^{\circ} 00^{\prime} \mathrm{E}$ \\
\hline
\end{tabular}

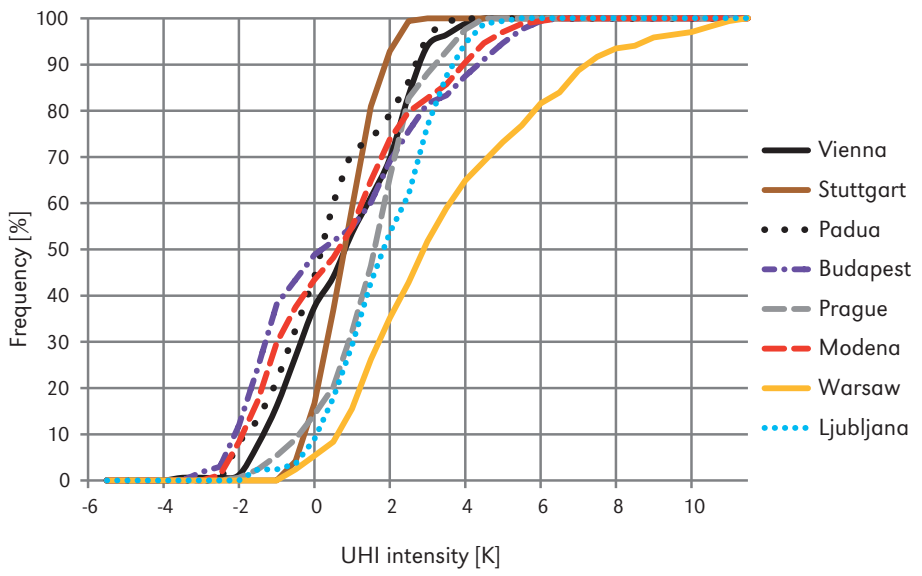

Figure 1. Cumulative frequency distribution of UHI intensity for a one week summer period

The reference week data clearly demonstrate the existence and significant magnitude of the UHI effect in participating cities, especially during the night hours (Fig. 3). However, the time-dependent UHI patterns vary considerably across the participating cities. 


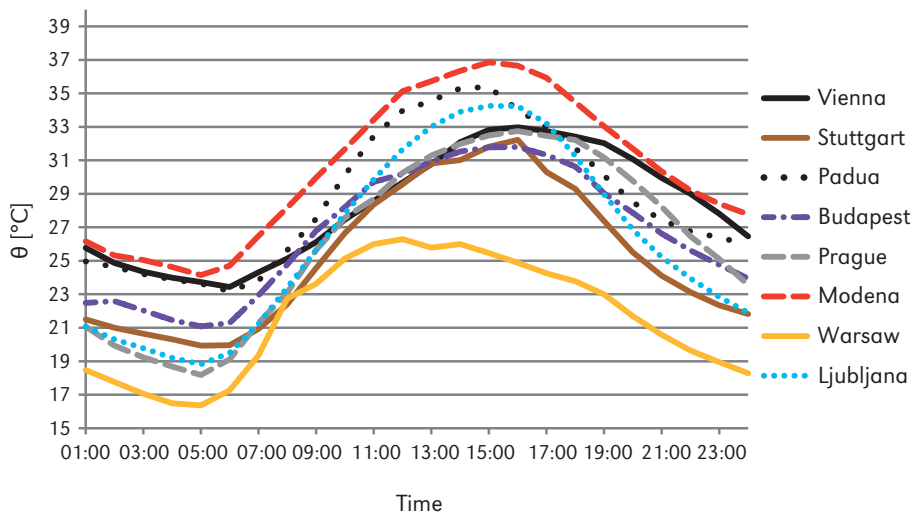

Figure 2. Mean hourly urban temperature for a reference summer day

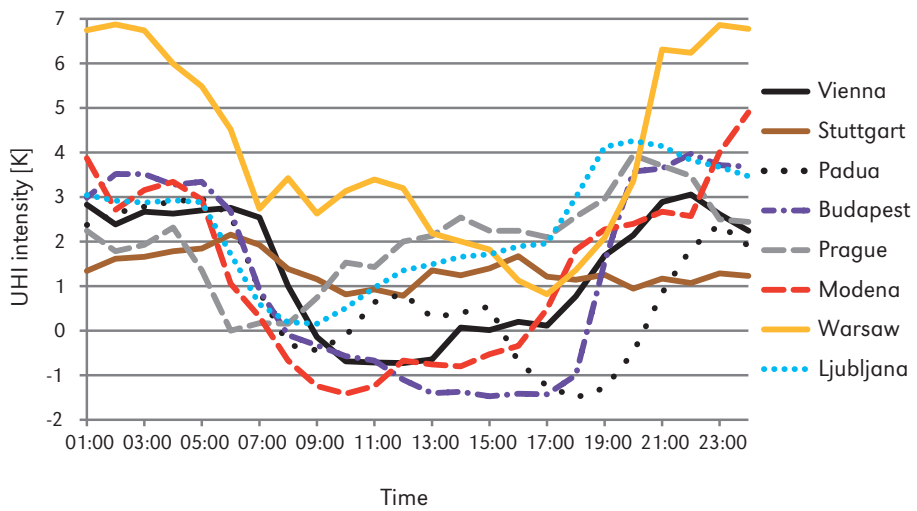

Figure 3. Mean hourly UHI intensity distribution for a reference summer day

The UHI pattern differences are also visible in the cumulative frequency distribution curves of Figure 1. In this Figure, a shift to the right denotes a larger UHI magnitude.

\section{Long-term analyses of the observations}

Figures 4 and 5 show the (mean annual) urban and rural temperatures respectively over a period of 30 years. Figure 6 shows the long-term UHI intensity trend over the same period. The historical temperature records suggest an upward trend concerning both urban and rural temperatures (Fig. 4, 5). Consistent with regional and global temperature trends, a steady increase in rural temperatures of up to about $2.5 \mathrm{~K}$ can be observed in all selected cities (with the exception of Budapest). This might be due to the small sample of data set obtained, as this particular weather station was installed in the year of 2000. In the same 30-years period, the mean annual urban temperature rose somewhere between $1 \mathrm{~K}$ (Stuttgart) and 3 K (Warsaw). Note that, while both rural and urban temperatures have been increasing, the value of the UHI intensity has been rather steady. Our data suggest increasing UHI intensity trends in Warsaw and Ljubljana, whereas a slight decrease can be discerned from Stuttgart and Prague data (Fig. 6). 


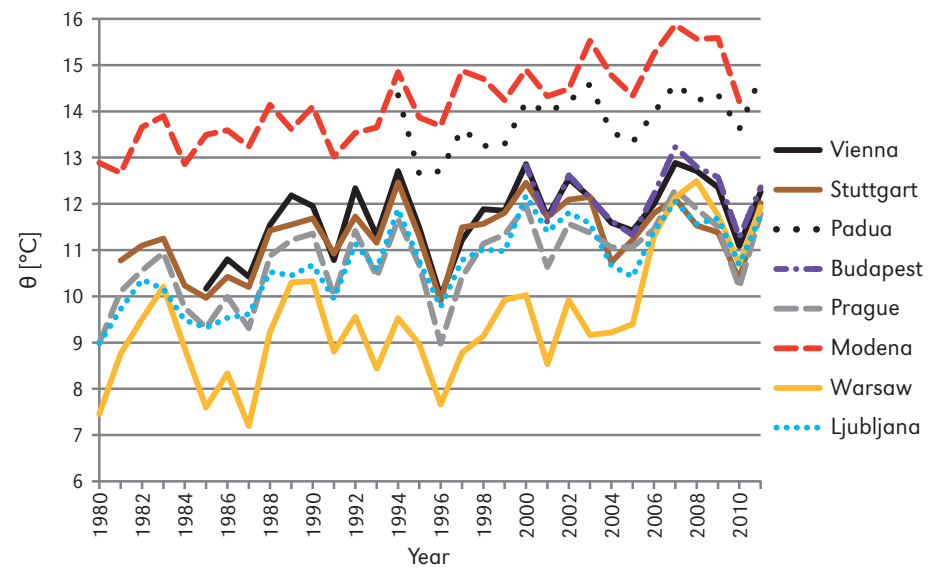

Figure 4. Development of (mean annual) urban temperatures over a period of 30 years

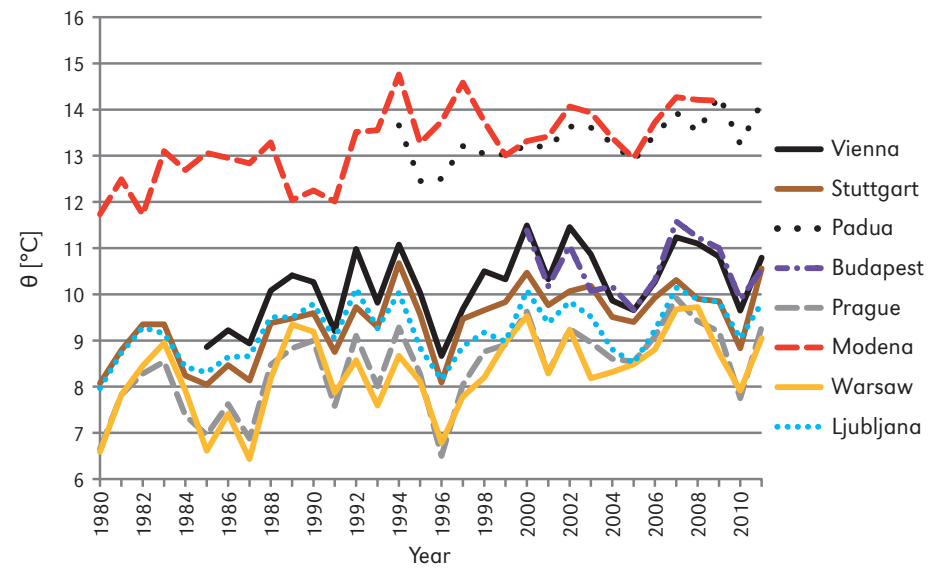

Figure 5. Development of (mean annual) rural temperatures over a period of 30 years

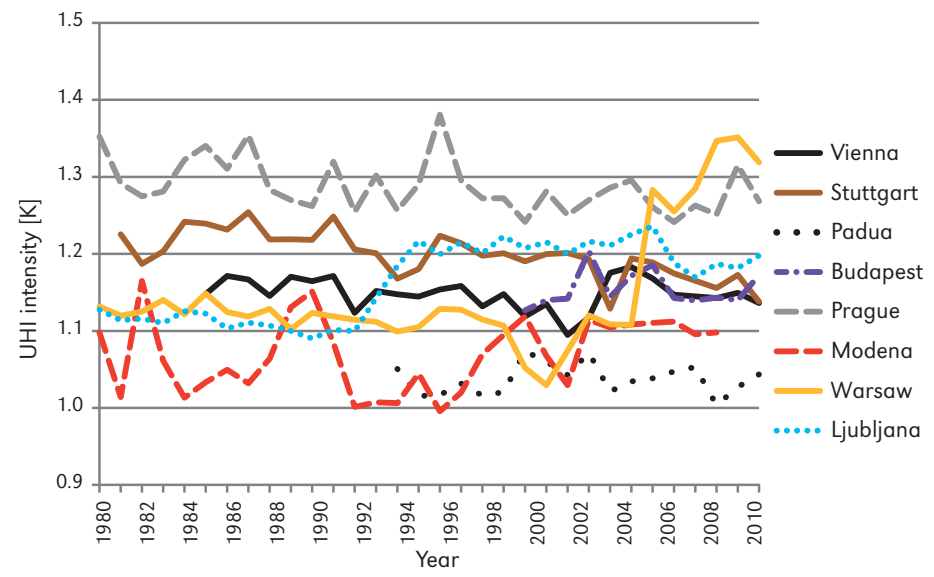

Figure 6. Long-term development of the $\mathrm{UHI}$ intensity over a period of 30 years 


\section{Systematic framework}

Within the aforementioned project, a systematic framework was developed to assess - for a specific urban location, hereafter referred to as urban unit of observation (U2O) - the urban heat island phenomenon, to specify potential mitigation and adaptation measures, and to evaluate such measures via adequate modelling approaches. The framework involves the following steps:

1) Definition of 'Urban Units of Observation' (U2O): These are properly bounded areas within an urban setting selected as the target and beneficiary of candidate UHI mitigation measures;

2) Description of the status quo of $\mathrm{U} 2 \mathrm{O}$ in terms of a structured set of geometric and physical properties;
3) Specification of the existing UHI intensity;

4) Specification of the candidate mitigation measures in terms of projected changes to the geometric and/or physical properties captured in step ii above;

5) Prediction of the effect of mitigation measures using empirically-based and/or numeric models;

6) Expression of the mitigation measures' impact in term of predicted changes in $\mathrm{UHI}$ intensity;

7) Overall evaluation of the mitigation measures' effectiveness on the basis of modelling results together with their estimated financial and logistic ramifications.

In this framework, the notion of $\mathrm{U} 2 \mathrm{O}$ is applied to systematically address the local variation of the urban climate throughout a city. A spatial dimension (diameter)

Table 5. Variables to capture the geometric properties of an $\cup 2 \mathrm{O}$

\begin{tabular}{|l|l|}
\hline \multicolumn{1}{|c|}{ Geometric properties } & \multicolumn{1}{|c|}{ Definition } \\
\hline $\begin{array}{l}\text { Sky View Factor } \\
\text { Aspect ratio }\end{array}$ & Fraction of sky hemisphere visible from ground level \\
Built area fraction & Mean height-to-width ratio of street canyons \\
Unbuilt area fraction & The ratio of building plan area to total ground area \\
Impervious surface fraction & The ratio of unbuilt plan area to total ground area \\
Pervious surface fraction & The ratio of unbuilt impervious plan area to total ground area \\
Mean building compactness & The ratio of unbuilt impervious surface area to total ground area \\
Built surface fraction & The ratio of built volume (above terrain) to total building plan area \\
Wall surface fraction & The ratio of total built surface area to total built area \\
Roof surface fraction & The ratio of total wall area (above terrain) to total built area \\
Mean sea level & The ratio of total roof area to total built area \\
\hline
\end{tabular}

Table 6. Variables to capture the surface and material properties of an $\cup 2 O$

\begin{tabular}{|l|l|}
\hline \multicolumn{1}{|c|}{ Surface/material properties } & \multicolumn{1}{c|}{ Definition } \\
\hline Reflectance/albedo & $\begin{array}{l}\text { Fraction of reflected direct and diffuse shortwave radiation } \\
\text { Emissivity }\end{array}$ \\
Thermal conductivity of a surface to emit energy by radiation (longwave) \\
Property of a material's ability to conduct heat, given separately for \\
impervious and pervious materials \\
Specific heat capacity & $\begin{array}{l}\text { Amount of heat required to change a body's temperature by a given } \\
\text { amount, given separately for impervious and pervious materials } \\
\text { Mass contained per unit volume, given separately for impervious and } \\
\text { pervious materials } \\
\text { Heat flux density from fuel combustion and human activity (traffic, } \\
\text { industry, heating and cooling of buildings, etc.) }\end{array}$ \\
\hline
\end{tabular}


of approximately 400 to $1000 \mathrm{~m}$ has been targeted for $\mathrm{U} 2 \mathrm{O}$, indicating common features in view of geometry, massing, or other aspects of the physical structure. As the urban microclimate is believed to be influenced by different urban morphologies, structures, and material properties, a set of related variables were identified and included in our framework.

Toward this end, a set of essential geometric and physical features was derived (Tab. 5, 6) based on past research (Nowak 2002; Piringer et al. 2002; Burian et al. 2005; Ali-Toudert \& Mayer 2006; Kiesel et al. 2013; Mahdavi et al. 2013). The geometric properties are meant to capture the urban morphology of an U2O (Burian et al. 2005). The physical properties describe mainly the thermal characteristics of urban surfaces. These properties are often considered as fundamental factors in view of the heat balance of urban systems (Rosenfeld et al. 1995).

To derive the specific values of the abovementioned variables for the selected urban areas, we used data provided by the city of Vienna in a form of a Digital Elevation Model (DEM). The DEM consisted of a terrain and a surface model, including building footprints in form of closed polygons associated with building height data (which indicates the height of the building eaves). QGIS (Quantum GIS 2013), an open source Geographic Information System, was used to visualize, manage, and analyse the data. A specific set of algorithms was developed (Glawischnig et al. 2014) and further used for the quantitative analysis of the microclimatic attributes. Note that the efficient computation of urban morphology variables requires detailed urban databases containing comprehensive spatial information. However, such data is at times difficult to obtain. Some local municipalities and commercial vendors provide digital datasets. The number of such data repositories is expected to increase in future.

\section{Evaluation of UHI mitigation measures}

Once U2Os and their respective variables are defined, potential mitigation measures (Tab. 7) may be expressed in terms of respective changes to the variable attributes. For example, introduction of green roofs or green facades in an U2O would modify the variables pertaining to surface albedo, emissivity, thermal conductivity, specific heat capacity, and density.

Table 7 provides a concise summary of the most common mitigation measures. These measures can be divided into three main realms of interventions: buildings, pavements, and vegetation. Table 7 also includes a detailed description of expected benefits of such measures.

Table 7. A summary of principal mitigation measures

\begin{tabular}{|l|l|l|}
\hline Category & Measure & Expected benefit \\
\hline Buildings & $\begin{array}{l}\text { Cool roofs } \\
\text { Green roofs } \\
\text { Green facades }\end{array}$ & $\begin{array}{l}\text { High solar reflectance and high thermal emissivity } \\
\text { Shading (intensive green roofs) and evapotranspiration } \\
\text { Reducing ambient air temperature, shading properties, nat- } \\
\text { ural cooling, control airborne pollutants, energy efficiency } \\
\text { Reducing cooling/heating load, reducing ambient air tem- } \\
\text { Façade construction and retrofit } \\
\text { perature, improving building envelope quality }\end{array}$ \\
& $\begin{array}{l}\text { Geometry of urban canyon (new } \\
\text { projects) } \\
\text { Cool pavements } \\
\text { Gervious pavements } \\
\text { Planting trees within the urban } \\
\text { canyon } \\
\text { Parks, green areas }\end{array}$ & $\begin{array}{l}\text { Fresh air advection, cool air transport into the city } \\
\text { Decreasing ambient air temperature } \\
\text { Storm water management } \\
\text { Shading and evapotranspiration, lower peak summer air } \\
\text { temperatures, reducing air pollution }\end{array}$ \\
\hline
\end{tabular}


Finally the impact of those mitigation measures can be estimated based on appropriate calculation tools and modelling methods. For this purpose we considered two principal approaches: statistical analysis of empirical data and numeric (typically CFD-based) computational models. Correlations between measured urban heat island intensity in different locations within an urban environment and the physical features of these locations can be exploited to derive empirically based estimation methods. For numeric computation, different simulation tools can be applied, ranging from regional climate models to single-building models (Mirzaei 2010). To illustrate the application of the framework, a case study from the aforementioned EU project is presented below. The case study concerns a U2O in the centre of Vienna, Austria. Figure 7 shows the existing attributes of the variables for this $\mathrm{U} 2 \mathrm{O}$ together with the changes in these variables as a consequence of three envisioned mitigation measures: 1) Planting trees within the urban canyon; 2) Green roofs; 3) A combination of measures 1 and 2 . In this case, the estimation of the implications of the mitigation measures was conducted using ENVI-met 4.0 as a numeric simulation application (Huttner \& Bruse 2009). Given the known constraints of numerical models, especially in terms of domain size, resolution, and the range of variables they can consider, the accuracy of the simulation-based predic- tions strongly rely on systematic calibration processes (Maleki et al. 2014). Figure 8 shows the modelling results in terms of predicted reduction of $\mathrm{UHI}$ index in the course of a reference summer day.

\section{Conclusion}

We presented the results of an ongoing EU-supported project concerned with the extent of the UHI phenomena in a number of Central European cities. The objectives of this project are to provide a common understanding of the UHI effects and to conceive and evaluate appropriate mitigation and adaptation measures. Short-term and long-term data with regard to urban and rural temperatures demonstrate the existence and significant magnitude of the $\mathrm{UHI}$ effect in a number of Central European cities. Furthermore observations based on hourly data display distinguished patterns implying larger UHI intensities during the night hours. To address the need for effective means of evaluating and mitigating UHI effects, a systematic framework was developed and tested within the collaborative context of an EU project. Thereby, a number of geometric (morphological) and semantic (material-related) variables of the urban environment were identified that are hypothesized to influence UHI and the urban microclimate variance. The deployment of this framework and a CFD-based

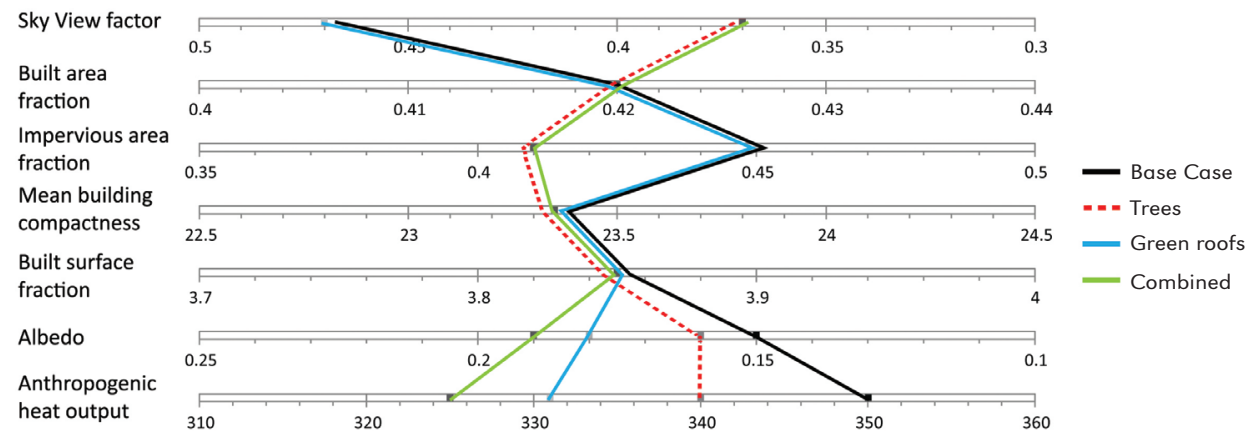

Figure 7. The existing values of the $\cup 2 O$ variables for the Vienna case study together with modified values associated with proposed mitigation measures 


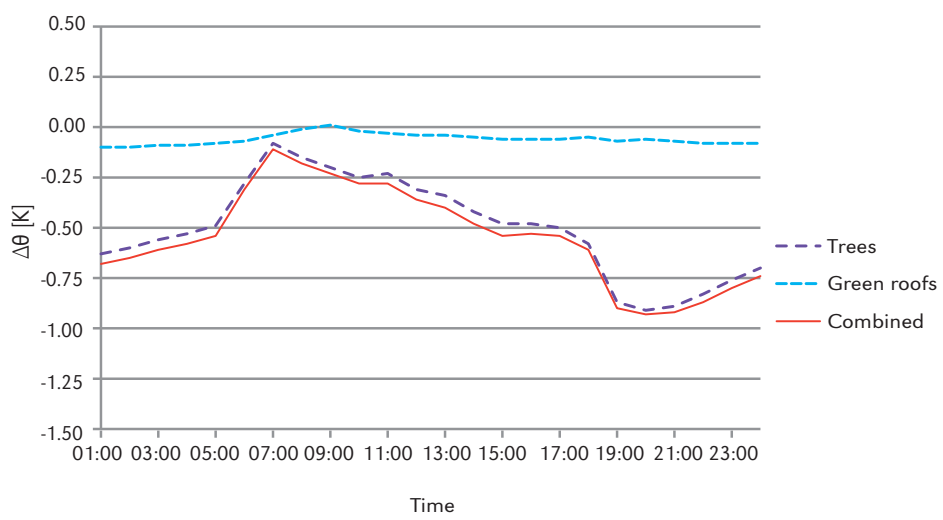

Figure 8. The modelled mean hourly temperature difference ('Innere Stadt', Vienna)

urban climate modelling tool was exemplified using the case of an urban unit of observation in the city of Vienna. Ongoing work further explores and statistically analyses the link between UHI intensity and salient urban variables such as urban density and morphology, block layout, canyon geometry, surface properties, vegetation, bodies of water industrial sites, transportation systems and infrastructures. This work is expected to not only provide empirical data for the validation of numeric models, but also to support the formulation of simplified approaches toward estimation of mitigation measures effectiveness in view of UHI phenomena.

\section{References}

AKBARI H., 2005. Energy saving potentials and air quality benefits of urban heat island mitigation. Lawrence Berkeley National Laboratory, http://escholarship.org/uc/item/4qs5f42s [2 June 2014].

Akbari H., Pomerantz M., Taha H., 2001. Cool surfaces and shade trees to reduce energy use and improve air quality in urban areas. Solar Energy, vol. 70, no. 3, pp. 295-310.

\section{Acknowledgements}

This project was funded in part within the frame-work of the EU-Project 'Development and application of mitigation and adaptation strategies and measures for counteracting the global Urban Heat Islands phenomenon' (Central Europe Program, No. 3CE292P3).

Editors' note:

Unless otherwise stated, the sources of tables and figures are the author(s), on the basis of their own research.

AleXANDRI E., 2007. Green cities of tomorrow? Portugal SB07. Sustainable Construction, Materials and Practices, pp. 710-717.

Ali-Toudert F., Mayer H., 2006. Numerical study on the effects of aspect ratio and orientation of an urban street canyon on outdoor thermal comfort in hot and dry climate. Buildings and Environment, vol. 41, no. 2, pp. 94-108.

Arnfield A.J., 2003. Two decades of urban climate research: A review of turbulence, exchanges of energy and water, and the urban heat island. International Journal of Climatology, vol. 23, no. 1, pp. 1-26. 
BŁAŻEJCZYK K., BĄKOWSKA M., WIĘCŁAW M., 2006. Urban heat island in large and small cities. Proceedings of the 6th International Conference on Urban Climate, Göteborg, Sweden: 12-16 June, 2006, pp. 794-797.

Burian S.J., Han W. S., Brown M. J., 2005. Morphological analysis using 3D Building Databases: Oklahoma City, Oklahoma. Los Alamos National Laboratory, LA-UR-05-1821, http:// www.docstoc.com/docs/97552646/Morphological-Analyses-using-3D-Building-DatabasesOklahoma [2 June 2014].

Gaffin S.R., Rosenzweig C., Khanbilvardi R., Parshall L., Mahani S., Glickman H., Goldberg R., Blake R., Slosberg R. B., Hillel D., 2008. Variations in New York city's urban heat island strength over time and space. Theoretical and Applied Climatology, vol. 94, no. 1-2, pp. 1-11.

Glawischnig S., Kiesel K., Mahdavi A., 2014. Feasibility analysis of open-government data for the automated calculation of the micro-climatic attributes of Urban Units of Observation in the city of Vienna. Proceedings of the 2nd ICAUD International Conference in Architecture and Urban Design, Epoka University, Tirana, Albania: 8-10 May 2014.

Grimmond C.S.B., 2007. Urbanization and global environmental change: local effects of urban warming. Cities and Global Environmental Change, vol. 173, no. 1, pp. 83-88.

Grimmond C.S.B., Cleugh H., Oke T.R., 1991. An objective urban heat storage model and its comparison with other schemes. Atmospheric Environment, vol. 25B, no. 3, pp. 311-326.

Harlan S.L., Ruddell D.M., 2011. Climate change and health in cities: impacts of heat and air pollution and potential co-benefits from mitigation and adaptation. Current Opinion in Environmental Sustainability, vol. 3, no. 3, 126-134.

Hart M., Sallor D.J., 2007. Assessing causes in spatial variability in urban heat island magnitude. Seventh Symposium on the Urban Environment, San Diego, CA: 9 September 2007, https://ams.confex.com/ams/pdfpapers/127284. pdf [1 June 2014].

HuttNer S., BRUSE M., 2009. Numerical modelling of the urban climate - A preview on ENVI-met 4.0. 7th International Conference on Urban Climate ICUC-7, Yokohama, Japan: 29 June - 3 July, http://www.envi-met.com/documents/ papers/ICUC7_ModellingV4.pdf [2 June 2014].
Kiesel K., Vuckovic M., Mahdavi A., 2013. Representation of weather conditions in building performance simulation: A case study of microclimatic variance in Central Europe. Proceedings of BS2013: 13th International Conference of the International Building Performance Simulation Association, Chambéry, France: August 26-28, http://eu-uhi.eu/cz/download/thematic_documents/IBPSA\%202013\%20final.pdf [3 July 2014].

Kleerekoper L., van Esch M., Salcedo T.B., 2012. How to make a city climate-proof, addressing the urban heat island effect. Resources, Conservation and Recycling, vol. 64, pp. 30-38.

Maleki A., Kiesel K., Vuckovic M., MahdaVI A., 2014. Empirical and computational issues of microclimate simulation [in:] M. Linawati, S. Mahendra, E. J. Neuhold, A. Min Tjoa, I. You (eds.), Lecture Notes in Computer Science 8407, Information and Communication Technology, Proceedings of Second IFIP TC5/8 International Conference ICT-EurAsia 2014, Bali, Indonesia: April 14-17, 2014, Springer, pp. 78-85.

Mirzael P.A., Haghighat F., 2010. Approaches to study Urban Heat Island - abilities and limitations. Building and Environment, vol. 45, no. 10, pp. 2192-2201.

Nowak D.J., 2002. The effects of urban trees on air quality. http://www.nrs.fs.fed.us/units/ urban/local-resources/downloads/Tree_Air_ Qual.pdf [3 July 2014].

OKE T.R., 1972. City size and the urban heat island. Atmospheric Environment, vol. 7, no. 8, pp. 769-779.

OKE T.R., 1981. Canyon geometry and the nocturnal urban heat island comparison of scale model and field observations. Journal of Climatology, vol. 1, pp. 237-254.

Piringer M., Grimmond C.S.B., Joffre S.M., Mestayer P., Middleton D.R., Rotach M.W., Baklanov A., de Ridder K., Ferreira J., Guilloteau E., Karppinen A., Martilli A., Masson V., TOMBROU M., 2002. Investigating the surface energy balance in urban areas - recent advances and future needs. Water, Air and Soil Pollution: Focus 2, no. 5-6, pp. 1-16.

QUANTUM GIS, 2013. http://www.qgis.org/en/ site/.

Rosenfeld A.H., Akbari H., Bretz S., Fishman B.L., KURN D.M., Sallor D.J., TAHA H., 1995. Mitigation of urban heat islands: materials, utility 
programs, updates. Energy and Buildings, vol. 22, no. 3, pp. 255-265.

ShISHEGAR N., 2013. Street design and urban microclimate: Analysing the effects of street geometry and orientation on airflow and solar access in urban canyons. Journal of Clean Energy Technologies, vol. 1, no. 1, pp. 52-56.

Stewart I.D., OKe T.R., 2012. Local Climate Zones for urban temperature studies. Bulletin of the American Meteorological Society, vol. 93, no. 12, pp. 1879-1900.
TAHA H., 1997. Urban climates and heat islands: albedo, evapotranspiration, and anthropogenic heat. Energy and Buildings, vol. 25, no. 2, 99-103.

UNGER J., 2004. Intra-urban relationship between surface geometry and urban heat island: review and new approach. Climate Research, vol. 27, pp. 253-264.

Voogt J.A., 2002. Urban Heat Island [in:] T. Munn (ed.), Encyclopedia of Global Environmental Change, vol. 3, Chichester: Wiley, pp. 660-666. 